Año XLVIII. urtea

$122-2016$

Uztaila - abendua

Julio - diciembre

Sor की:

sus

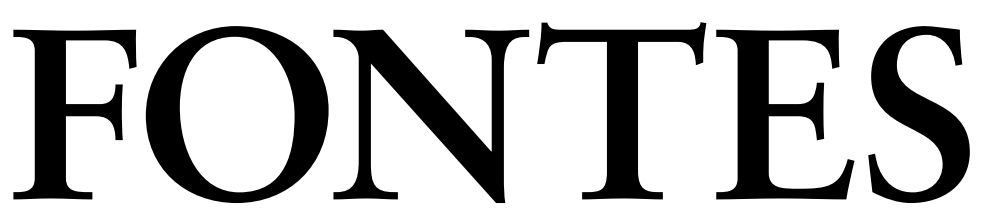

LINGVÆ

VASCONVM

STVDIA ET DOCVMENTA

SEPARATA

\title{
Urretabizkaiaren eta Sarrionandiaren itzulpen-habitusak
}

Miren Ibarluzea

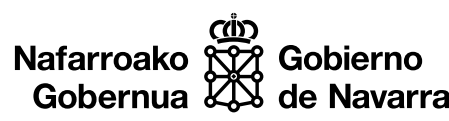

0000 


\section{Sumario / Aurkibidea}

\section{Fontes Linguae Vasconum. Studia et Documenta}

Año XLVIII. urtea - N. o 122. zk. - 2016

Uztaila - abendua / Julio - diciembre

Erroibarko aldaeraren inguruan

(3 - Hego Erroibarko azpialdaera. Bigarren erdia)

Koldo Artola

Etxarrierako hitano-alokutiboa

Jose Luis Erdozia

An introduction to Basque aspiration: the contribution of onomastics

Patxi Salaberri Zaratiegi, Iker Salaberri Izko

Urretabizkaiaren eta Sarrionandiaren itzulpen-habitusak

Miren Ibarluzea

Julian Gaiarreren euskal gutuna: edizioa eta azterketa

Koldo Ulibarri

Zozo zuriaren xerka: euskararen optatiboaren historia

Manuel Padilla-Moyano

Euskarazko erlatiboen diakroniaz: testu zaharren azterketa

Dorota Krajewska 


\title{
Urretabizkaiaren eta Sarrionandiaren itzulpen-habitusak
}

\author{
Miren IbarluZeA ${ }^{1}$ \\ $\mathrm{UPV} / \mathrm{EHU}$
}

\section{GALDETEGI BATETIK ITZULPEN-LANTEGIRA, ETA HANDIK BERTORA}

«Idazlea itzultzaileen lantegian» izeneko itzulpen-mintegia antolatzen du Euskal Itzultzaile, Interprete eta Zuzentzaileen Elkarteak (EIZIE) urtero². 2016koa mintegi berezia izan zen: EIZIEk, Etxepare Euskal Institutuak eta DSS2016 Fundazioak elkarrekin prestatutako «Itzultzaile Berriak» programaren baitan txertatu zen ${ }^{3}$. «Deserria itzultzen» izenburupean egin zen lantegia, eta, Arantxa Urretabizkaiaren Koaderno gorria eta Joseba Sarrionandiaren hainbat poema oinarri hartuta, hiru egunez lanean aritu ziren atzerritik gurera euskara ikastera etorritako itzultzaileak ${ }^{4}$. Itzulpen-saioez gainera, bestelako bisitak (bertatik bertarakoak eta bideo- zein ahots-grabazio bidezkoak) izan zituzten itzultzaileek; batetik, Urretabizkaiak eta Sarrionandiak zenbait gako eman zizkieten itzultzaileei euren lanen inguruan, bai eta itzultzaileek lantegira ekarritako lehenbiziko bertsioen inguruan sortutako zalantzei erantzun ere; bestalde, Iñaki Iñurrieta eta Eva Linazasoro itzultzaileak gonbidatu zituzten saioetara, Urretabizkaiaren

1 Lan hau «Memoria Historikoa Literatura Iberiarretan» IT 1047-16 ikerketa taldearen baitan egin da. Bihoazkie nire eskerrik beroenak artikulu hau egiteko aitzakia eman zidan Itziar Otegiri, Deserria itzultzen mintegira gonbidatzeagatik, eta Aiora Jakari, testua irakurrita ohar interesgarriak egiteagatik.

2 2004az geroztiko lantegien berri esteka honetan: <http://www.eizie.eus/Jarduerak/idazlea_eta_itzultzaileak>.

3 Ikusi proiektuari buruzko informazioa hemen: <http://www.eizie.eus/Jarduerak/itzultzaile_berriak>.

4 Laura Liubinavičiūte (Lituania), Mariya Petrova Pachkova (Bulgaria), Barbara Pregelj (Eslovenia), Katarzyna Sosnowska (Polonia), Karina Mischenkova (Errusia), Merilin Kotta (Estonia) eta Lenka Nižnanská (Txekiar Errepublika). 
eta Sarrionandiaren lan batzuk (hurrenez hurren) gaztelaniara itzultzean izandako esperientziaz hitz egiteko; azkenik, Aiora Jakak Sarrionandiaren itzulpenen inguruan egindako lana aurkeztu zuen, eta nik neuk 2013an hainbat idazle garaikideren itzulpen-ohiturak, jarrerak eta esperientziak aztertzeko egindako lan batetik ${ }^{5}$ Urretabizkaiarenak eta Sarrionandiarenak erauzi eta kontatu nituen. Bada, 2015eko artikulu hura elkarrizketatutako idazleen erantzunen irakurketa orokor bat da, baina argitaragabeak dira idazle bakoitzaren erantzunak; beraz, interesgarri iritzi genion, abagune hura baliatuta, bi idazleon erantzunak jaso eta erkatuta artikulu batean emateari. Habitus kontzeptuak biltzen ditu eragileen ohiturak, jarrerak eta esperientziak, eta kontzeptu horri buruzko azalpen teorikoa egingo dugu artikuluaren lehenbiziko atalean; ondoren, bigarren atalean, Urretabizkaiaren eta Sarrionandiaren habitusetan sakonduko dugu: itzulpenaz eta itzulpengintzaz egindako galderen erantzunak jasoko ditugu, bai eta iruzkindu eta erkatu ere. Hain zuzen ere, 2013an pasarazi genien galdetegiaren ${ }^{6}$ ardatza itzulpen-habitusa izan zen, kontzeptu horrek barne hartzen dituen ideien bilketa egitea izan baitzen galdera-bilduma haren helburua.

\section{HABITUSA: GIZARTE-EREMU BATEAN JOKATZEA}

Pierre Bourdieu frantziar soziologoak elkarrekin lotutako hiru kontzeptu baliatzen ditu errealitate sozialak azaltzeko: eremua, kapitala eta habitusa. Hiru kontzeptuak elkarrekin baino ezin daitezke ulertu, hiru kontzeptuek elkarrekin funtzionatzen dute, hiru kontzeptuek elkar definitzen dute (Vizcarra, 2002). Bada, hauxe da osatzen duten sorgin-gurpila: harreman historiko, botere-sare edo balio ideologiko, kultural, ekonomiko zein sinbolikoek, hots, kapitalek baldintzatutako kokaguneen sarea da eremua, eta sare horrek norbanakoarenean utzitako lorratza da habitusa. Bourdieuren arabera, unibertso sozialen edo eremuen egiturek izaera edo objektibitate bikoitza dute: materiala eta sinbolikoa; nolanahi ere den, bi objektibitate mailak loturik daude. Beraz, itzulpengintzari lotutako errealitate bat deskribatzeko, ezin dugu soilik errealitate materiala kontuan hartu; alegia, kontua ez da soilik nork zer itzuli duen eta nolakoa den testua. Kontuan hartu behar da, halaber, prozesuan parte hartzen duten eragileen esperientzia; itzultzaileen jarrerak, joerak eta hautemate-kategoriak deskribatu behar dira, besteak beste. Bourdieuren hiru kontzeptu nagusi horiek dagokigun gaira ekarrita, Urretabizkaia eta Sarrionandia gizarte-eremu (euskal literatur itzulpenaren eremua) jakin bateko eragile dira, eta eremu horretako sarean habitus jakin bat dute; bada, euren esperientziak eta ideiak (baita itzulpenari dagozkienak ere) eremu sozio-ekonomiko, politiko eta kultural jakin bati lotuta ulertzekoak dira, non euskarak berak eta euskarazko itzulpenak balio edo kapital jakin bat baitu. Eremua edo sarea ehuntzen duten egiturek, praktikek eta jarrerek eragin egin dute eurengan, bai eta baldintzatu eta eraiki ere euskal itzulpenaz eta itzulpenaz oro har duten pertzepzioa, eurek euren aldetik jasotako inputekin batera.

5 2015ean argitaratu zen lan horren emaitza; ikusi Ibarluzea, 2015.

6 Esan bezala, Ibarluzea, 2015 lanerako idazleek 2013an erantzundako galdetegiak argitaragabeak dira. Hala ere, bibliografian jaso dira eta honela izendatuko dira hemen: Sarrionandia, 2013 eta Urretabizkaia, 2013. 
Euskal itzulpen-eremua eremu magnetiko batekin erka daiteke, non indar objektibo batzuek eragin egiten dieten eremuan sartzen diren eragile eta objektu guztiei, eta eremuaren muga eremuaren beraren eraginpean dagoen espazioak markatzen duen; hala, Urretabizkaia eta Sarrionandia euskal itzulpen-eremuko parte dira, inoiz edo behin, modu batera edo bestera, euskal itzulpengintzaren eremuan sartu direlako, idazle legez, itzultzaile legez zein bitartekari legez. Konparazioa joko-esparruarekin eginez gero, euskal itzulpen-eremua karta-joko jakin bat da: Urretabizkaia eta Sarrionandia jokalariak dira eta karta jakinak dituzte, eta kartek balio zehatza dute. Jokoaren arauak eremukideek eta erronka komunek ezartzen dituzte, arauak errespetatu egin ohi dira (edo ez), eta lankidetza zein gatazka gerta daiteke jokalarien artean. Gainera, erronkari ekiteko, estrategia jakinak zein kapitalak balia daitezke. Jokalari bakoitzak jokoaz duen jakintzaren arabera eta jokoan duen esperientziaren arabera jardun ohi du, hots, bere joko-habitusaren arabera.

Habitusa, beraz, gorputz jakin baten sakonean sedimentatutako egoera birtuala da, modu batera edo bestera erreakzionatzera bideratzen duena (Bourdieu eta Wacquant, 1992: 28). Beste hitz batzuekin esateko, gramatika unibertsal moduko bat da habitusa, barneratutako jarrera-sistema bat, zerikusia duena norberaren pertzepzioekin, pentsamenduekin, diskurtsoarekin, ekintzekin eta praktikekin. Era berean, eskema sortzailea ere bada habitusa, askotariko egoeren aurrean modu batera edo bestera jokarazten edo erantzunarazten duena, ezen barneratutako eskemaren arabera jarduten dute subjektuek. Nolanahi ere den, habitusa ez da finkoa, aldatu egiten da bai egoera jakinaren arabera, bai subjektuen ibilbidean; hala, habitusari lotzekoak dira bai ohiturak, bai bat-bateko erantzunak. Bikoitza da habitusa zentzu askotan: barneratu eta kanporatu egiten da, kolektiboa eta pertsonala da; hots, norbanakotasuna eta gizartetasuna artikulatzen ditu.

\section{URRETABIZKAIAREN ETA SARRIONANDIAREN ITZULPEN-HABITUSAK}

Urretabizkaiaren eta Sarrionandiaren itzulpen-habitusez ariko gara hemen, eta bi idazleen itzulpen-ohiturek eta jarrerek ardaztuko dituzte datozen lerrook. Urretabizkaiak eta Sarrionandiak itzulpenarekin duten loturez, euskal itzulpengintzari egindako ekarpenez eta itzulpenak eurengan utzitako lorratzaz ariko gara. Horretarako, arestian esan bezala, 2015ean Estudios de Traducción aldizkarian argitaratutako «The Translation Habitus of Contemporary Basque Writers» artitikulurako erantzun zuten galdetegia hartuko dugu ardatz.

Habitusa ardatz duen artikulu horretan, hamabost idazle garaikidek ${ }^{7}$ hogei itauneko galdetegiari emandako erantzunen irakurketa orokorra egin genuen, sei ataletan:

7 Honako idazle hauek erantzun zioten galdetegiari artikulu hartarako: Arantxa Urretabizkaia, Mariasun Landa, Bernardo Atxaga, Aurelia Arkotxa, Joseba Sarrionandia, Itxaro Borda, Jon Alonso, Miren Agur Meabe, Xabier Mendiguren, Iban Zaldua, Kirmen Uribe, Ur Apalategi, Unai Elorriaga, Julen Gabiria, Harkaitz Cano. Gerora, Jose Agustin Arrietak eta Ramon Saizarbitoriak ere erantzun diote galdetegiari. 
1) hizkuntzen ikasketa-prozesua, 2) itzulpenarekiko lotura, 3) itzulpen-esperientziak, 4) euskal itzulpenari buruzko iritzia eta itzulpenak irakurtzeko ohiturak, 5) itzulpena fikzioan eta 6) itzulpenaz jarduteko metaforak. Izan ere, gai horiek denak barne hartzen ditu habitus kontzeptuak. Oro har, oso gertuko jarduera da itzulpena euskal idazle garaikideentzat, euren testuak zein inorenak itzuli izan dituzte, euskarara ekarritako literatura irakurtzeko ohitura gero eta handiagoa dute, itzulitako literatur lanak estiloa lantzeko eredutzat jotzen dituzte, itzulpengintzari buruzko mintegi zein ekitaldi publikoetan parte hartu dute, itzulpenari buruzko gogoetak plazaratu dituzte... Baina, salbuespenak salbuespen, oro har ez dute euren burua euskal itzulpengintzaren eremuko partaidetzat eta ez dute itzulpenarekiko lotura akademiko edo profesionalik: gizarte eleanitzeko literatur jarduerarekin lotutako ekintza da itzultzea euskal idazle garaikideentzat, bestela jokatzen dute euren testuak itzultzean eta inoren testuak itzultzean, itzulpen-eremu gero eta egituratuago baten beharra nabarmentzen dute eta joera nagusia literatur sorkuntza eta literatur itzulpena gero eta gehiago bereiztekoa da; izan ere, gero eta gehiago dira euren lanak ere itzultzaile baten esku uztearen aldekoak, eurak ere itzulpenerako hizkuntza-gaitasuna izan arren. Itzultzailearen figura gero eta positiboagoa da euskal idazleen artean, eta badirudi euskal itzulpengintzak bizi izandako erakundetzeak eta profesionalizazioak eragin egin duela autore garaikideen diskurtsoetan eta itzulpenarekiko jarreretan; hala nabari da, esaterako, fikzioan txertatu dituzten pertsonaia itzultzaileak karakterizatzean (Ibarluzea, 2015).

Datozen lerroetan Urretabizkaiak eta Sarrionandiak galdetegi hari emandako erantzunetan jarri nahi genuke arreta ${ }^{8}$, baina ez dugu hemen galdera bakoitzari banaka nork zer erantzun zion ikusteko «kopiatu eta itsatsi» egingo; 2015eko artikulu hartan egin genuen moduan, erantzunak multzokatu egingo ditugu, iruzkindu, eta tarteka bi idazleen aipuak txertatu, besteak beste bien jarrerak eta ideiak erkatuta.

Urretabizkaiak eta Sarrionandiak gaztelaniaz egin zituzten oinarrizko ikasketak eta gerora alfabetatu ziren euskaraz; euskaraz idazteko hautu ideologiko kontzientea egin zuten. Itzulpen-hizkuntzei dagokienez, frantsesa, gaztelania eta euskara baliatu izan ditu Urretabizkaiak itzulpenari lotu zaionean (Urretabizkaia, 2013); nolabait esateko, bere eremuari geografikoki lotutako hizkuntzak dira hirurak. Sarrionandiak, ostera, bestelako ikaskuntza-prozesuen bidez bereganatutako hizkuntzekin ere jardun du itzulpengintzaren eremuan: iurretarrak kontatutakoari jarraikiz, frantses irakurria baliatzeko gai da, eskolako ikasketak tarteko; galiziera Carabanchelen ikasi zuen preso batzuekin, eta portugesa Puerto de Santa Marían, irratia entzunez eta irakurriz; ingelesa unibertsitatean estudiatu zuela dio, bost urteko karrera egin zuela eta irakurketa-hizkuntza legez darabilela (Sarrionandia, 2013). Aiora Jakak doktorego-tesian (2012) aurreratzen zuenez, guk prestatutako galdetegiaren erantzunetan berretsi egiten du Sarrionandiak

8 Galdetegiak 2013ko udan erantzun zituzten idazleek eta argitaragabeak dira. Corken (Irlanda) aurkeztu genituen 2013ko udazkenean, gainerako idazleenekin batera, "Self Translation in the Iberian Peninsula» nazioarteko biltzarrean. 2015ean argitaratutako artikuluan galdetegi guztietatik ondorioztatutakoak eta hainbat aipu baino ez ziren argitaratu. 
zubi-hizkuntza gisa sarri baliatu izan duela gaztelania: «Hamahiru ate, Izkiriaturik aurkitu ditudan ene poemak, Hezurrezko xirulak eta halako liburuetan badira testu japoniarrak, palestinarrak, txinoak, apatxeak eta abar. Horiek denak itzultzeko zubihizkuntzak erabili ditut, jakina, sarritan gaztelera» (Sarrionandia, 2013).

Praktikari loturik bizi izan dute itzulpena batez ere Urretabizkaiak eta Sarrionandiak: itzulpenak egin izan dituzte, baina ez dute inongo ikastaro bereziturik egin gaiaren inguruan, ez eta itzulpenari lotutako mintegietan parte hartu ere. Itzulpenaren espazioan «modu bakarti eta intuitiboan mugitu» izan dela dio Sarrionandiak, adibidez (Sarrionandia, 2013). Urretabizkaiaren aldean, baina, gaiari buruzko gogoetarik idatzi izan du bere liburuetako hitzaurreetan, besteak beste?.

Urretabizkaiak kazetaritzarekin lotzen du bere ibilbide profesionala. Argi dio: «Kazetari naiz lanbidez eta, tarteka, libururen bat idazten dut»(Urretabizkaia, 2013). Itzulpenarekiko loturaz galdetuta, «Itzulpenak egiten hasi nintzen. Izan ere, nire izena azalean zeraman lehen liburua, Mendebaleko ekonomiaren historia (Lur, 1970), gazteleraz idatzitako testuak laburtuz eta itzuliz osatu zen» (idem). Lehenbiziko argitalpenerako bide izan zuen itzulpena Urretabizkaiak; gisa horretan, itzulpena bere burua publikoki inprimaturik agertzeko zubi izan zela esan dezakegu. Sarrionandiak zalantzazkotzat jotzen du bere profesioa bera: «Ez dakit idazle profesionala naizen, ze ez naiz lan aldetik antolatuta sentitzen, aspalditik hona denbora gehiena idazteko erabili dezakedan arren. Bakazioetakoa bezalakoa da nire bizitza, alde horretatik» dio (Sarrionandia, 2013). Itzulpenarekiko loturaz galdetuta, iraganera jauzi egin eta eskola garaietara jotzen du Sarrionandiak: eskolan Julio Cesarren Galietako Gerra itzultzen zutela gogoratzen du irriz. Letrekiko lehenbiziko lotura gogoratzeaz gain, zelanbait esateko, berezko egoera naturaltzat jotzen du itzultzea: «Ordurako elebiduna nintzen, euskaraz eta gazteleraz, orduko asimetria diglosiko itzelarekin. Dena dela, After Babel, komunikazio harreman guztietan dago itzulpena. Eta hor gabiltza gu, ahalegin batzuk eginez» (idem).

Oro har, beraz, bizitzako garai jakin batekin lotzen du Urretabizkaiak itzulpena, Lur taldean aritu zen garaiarekin, alegia, eta aitortzen du gaur egun itzulpengintzak ez duela «apenas lekurik» bere lanean. Sarrionandiak, ostera, egindako ibilbide literario jarraituari lotzen dio itzulpena: «Nik literaturarekin lotuta egin ditut itzulpen-ahalegin asko. Irakurtzeko edo idazteko modu bat izan da niretzat itzulpena. Itzultzea lan moduan hartu ez arren, orain egindako itzulpenen zerrendari begiratuz konturatzen naiz asko direla» (idem); bizitzako une jakin batekin soilik lotu ordez, umetatik gaur arteko errealitate eta jardun literario gisa dakusa itzulpena.

9 Alor hau Aiora Jakak ikertu du; sakondu nahi izanez gero, haren tesira (Jaka, 2012) eta artikuluetara jotzea du onena irakurleak. 
Atxagak berak azpimarratzen zuen ildo beretik ${ }^{10}$, Sarrionandiak ere diakroniari begiratu behar zaiola azpimarratzen du, ez dela bera gaurko egoera eta idazten eta itzultzen hasi zirenekoa:

Irakurtzeko eta idazteko modu bat izan da niretzat, esan bezala, baina nabarmendu nahi nuke gure literaturaren egoera orain berrogei urte: euskal literaturaren liburutegia oso urria zen, gure idazleen sortzeko ahalmenak ere oso mugatuak hainbat arrazoirengatik. Edozein literaturak literatura orokorraren parte izateko beste literaturekin harremanean izan behar badu, itzulpenen bidez batez ere, euskal literaturak itzulpen urjentzia are larriagoa zuen literatura autonomoa osatzeko, literatura batek behar duen gutxieneko materiala falta zuelako [...]. Urjentziak bestelakoak dira gaur egun, beharbada. Euskal literatura osatuta dago, itzulpengintza ere ondo antolatuta dago. Urrundik ikusita behintzat, lehen ezer ez zen, orain ja bada zerbait.

(Sarrionandia, 2013)

Urretabizkaia ere modu bertsuan abiatu zen idazkuntzan eta itzulpengintzan, euskarak askotariko testuak, erregistroak eta gaiak landu eta sortu behar zituen garaian. Bere hitzak ekarrita eta arestian aipatu dugun modu-moduan, itzultzen «hasi zen»; izan ere, Lur taldearen eskutik barneratu zen euskal letretan, Ramon Saizarbitoria eta Ibon Sarasola lagun: 1970ean Frantz Fanonen Afrika iraultzaren alde itzuli zuen, Sarasolarekin batera («Ibon Sarasolak eta biok, elkarren ondoan jarrita, esaldiz-esaldi itzuli genuen liburua. Nik frantsesetik, Sarasolak gazteleratik. Bion ustez hoberena zen esaldia aukeratzen genuen» dio; Urretabizkaia, 2013). Urte berean Mendebaldeko Ekonomiaren historia idatzi zuen Saizarbitoria eta Sarasolarekin batera. 1971n, M. Dobben Sozialismoaren frogantzak obra itzuli zuen eta, 1973an, A. Otazuren Euskal Berdintasuna. Orduantxe hasi zen sorkuntza-lanak argitaratzen, 1972ko «San Pedro bezperaren ondokoak» poema luzea plazaratu zuen sari bat tarteko. Ordutik aurrerakoan, Urretabizkaiak poesia ere landu izan du, baina narrazioan aritu da batez ere; ez du, baina, itzulpen gehiagorik egin, eta ez zaio inoiz inoren testu literarioak itzultzeari atxiki (autoitzulpenen bat kenduta). Itzulpena, beraz, euskal letren bidean egindako lehen pausoetako bat izan zen Urretabizkaiarenean, eta iraganari loturik dago bere ibilbidean. Bestelakoa da Sarrionandiaren kasua, hasierako garaietan ez eze, gerora ere konstante bat izan baita itzulpena haren ibilbidean:

Laurogeiko hamarkadan batez ere euskal literaturari gorputza emateko xedeak bultzatzen ninduela esango nuke: idazlanak, itzulpenak, apokrifoak eta abar, horretarako ziren. Ez dadila hori sakrifizio moduan ulertu, zeren batzuek dikotomia moduan planteatzen dituzte zeregin sozialak eta dibertsioa. Nik, ostera, oso ondo pasatu nuen,

10 Begiratu Ibarluzea, 2015. 
esate baterako, Izkiriaturik aurkitu ditudan ene poemak prestatzen: «hau euskal literatura da» proposatuz testu itzuliak eta apokrifoak ere atontzen nituen artean.

(Sarrionandia, 2013)

Itzulpena, beraz, behar sozial jakin bati erantzuteko bidea izateaz gainera, jolas ere izan da Sarrionandiarentzat.

Inoren testurik itzuli izan duen galdetuta, zerrendatu eta iruzkindu egiten ditu Sarrionandiak bere itzulpenak darabilgun galdetegiaren erantzunetan. Itzulpen gehientsuenak arrazoi literarioengatik egindako hautuz egin ditu, baina bada enkarguren bat ere tartean: irakurtzean gustatu eta hemeretzi-hogei urterekin itzuli zituen R. L. Stevensonen Gauerako aterpea eta Marcel Schwoben Haurren gurutzada; baina «lehenengoa lagun batek galdu zuen mozkor gau batean» eta «bestearekin ez dakit zer pasatu zen» dio (Sarrionandia, 2013). Ondoren T. S. Elioten The Waste Land: T. S. Eliot euskaraz etorri zen, Hordago argitaletxetan, 1983an; bada, hori ere gustatzen zitzaiolako itzuli zuen, bere kontura, eta Arestik Lau Kuarteto eta Juaristik Gizon Hutsak itzulita zeuzkatenez, hiru testuak batera argitaratu ziren. Kartzelan denborapasa itzulitako umore beltzeko ipuinak dira Hamahiru ate bildumakoak (Elkar, 1985), batzuk Mitxel Sarasketarekin batera egindakoak. Fernando Pessoaren O Marinheiro antzerkiaren itzulpena ere berdin egin zuen, kartzelan, denborapasa (Marinela, Susa, 1985). Kartzelan eta erbestean erdi broman egindako bertsiotzat jotzen ditu Izkiriaturik aurkitu ditudan ene poemak (Pamiela, 1985) eta Hezurrezko xirulak (Elkar, 1991). Susa argitaletxeak argitaratu zuen 1991ean Poemas naufragos (galegoz heldutako poemak): Manoel Antonio, Luis Amado Carballo, Álvaro Cunqueiro, Aquilino Iglesia Alvariño, Luis Pimentel, Luis Seoane, Celso Emilio Ferreiro eta Manuel Maríaren poemen bertsioak dira. Gero etorri zen S. T. Coleridgeren The Rhyme of the Ancient Mariner poemaren itzulpena (Marinel zaharraren balada, Pamiela, 1995) eta Manuel Bandeiraren poesiaren antologia itzulia (Pamiela, 1999), arrazoi literarioengatik aukeratutakoa hori ere, aurrekoak bezalaxe. "Irakurtzeko modu bat zen itzulpena egitea, edo idazteko modu bat» (Sarrionandia, 2013) azpimarratzen du behin eta berriz Sarrionandiak. Mandatuz ere egin izan ditu itzulpenak, eta euskarara itzulitako enkarguzko lan bakarra, esaterako, Xabier Mendigurenek proposatuta egin zuen ingelesetik (jatorrizkoa neederlanderazkoa da): Dolf Verroren Neure neure esklaboa (Elkar, 2009). Edonola ere, bestelako enkarguzko itzulpenak ere egin izan ditu iurretarrak, baina euskal itzulpen-eremutik kanpo (eta hargatik ez ote ditu sinatu euskal eremuan darabilen izenez?): «enkarguz, ogiagatik, beste itzulpen batzuk egin ditut, baina ingelesetik gaztelerara, eta izen-abizen asmatuekin sinatu ditut» aitortzen du Sarrionandiak ${ }^{11}$ (2013). Aitorpen horren harira ondorioztatu dezakegu jarrera eta praktika ezberdinduak dituela Sarrionandiak euskal literatura itzuliaren eremuan eta gainerako hizkuntzen eremuetan, eta eremu bakoitzerako izen-abizen edo ezizen ezberdinak darabiltza, gainera. Seguruenik, bestelako

11 Gaztelaniaz idatzi eta ezizenez sinatu izan duela ere aitortzen du: «Egin ditut liburu batzuk gazteleraz, baina zuzenki egin ditut gazteleraz eta, gainera, beste izenez sinatu ditut» dio (Sarrionandia, 2013). 
itzulpenik ere egin izan du Sarrionandiak, baina berak hitzez hitz dioenez: «Hainbat eskuizkribu galdu nituen gero kartzelan, trasladoetan-eta. Erbestean ere, behin baino gehiagotan galdu ditut paperak alde batetik bestera mugitzean» (Sarrionandia, 2013).

Kartzelan eta erbestean erdi broman egindako bertsiotzat jotzen dituen itzulpen horiei buruzko jakingarri gehiago Aiora Jakaren tesian (Jaka, 2012) eta artikuluetan aurki ditzake irakurleak. Sarrionandiak itzulpenarekin ez eze, irakurlearekin ere egiten du jolas: berak idatzitako jatorrizko testuak ematen ditu testu itzuliak balira bezala, fikziozko itzultzaileak txertatzen ditu eta egiazkoak balira bezala agertu... Guretzat erantzundako galdetegian, fikziozko itzultzaile eta itzulpenei buruz galdetutakoan, Jakak tesian plazaratutako hipotesiak berretsi egin zituen Sarrionandiak:

Ez dut gogoratzen orain halako pertsonaiarik nobelan edo ipuinetan. Izkiriaturik aurkitu ditudan ene poemak eta Hezurrezko xirulak liburuetan, ostera, halako pertsonaia asmatu batzuk agertzen dira. Nahualtetik euskaratutako testu baten itzultzailea, esate baterako, Jose Ramon Negrete. Autoretzaren kontzeptua apur bat urtzeaz batera, oraindik ere Mexikon erbesteratuta dagoen Jose Ramon Fuertes «Baltza» nire lagunari adarra jotzeko. Bestalde, itzultzea bera fikzio gai gisa erabili dut batzuetan, Kartzelako poemak liburuan esate baterako, hiru poema ematen dira testu txino baten hiru bertsio zeharo diferente emanez.

(Sarrionandia, 2013)

Baina, joko literario horiek kenduta, eta itzulpenari buruzko diskurtso postmodernoa badu ere, Aiora Jakak egindako testu-azterketei jarraikiz, aski hurbiletik jarraitzen die Sarrionandiak zubi-hizkuntzako testuei ${ }^{12}$. Izan ere, argi dauka Sarrionandiak auzia ez dela norberaren testuak edo inorenak itzultzea, autoretza onartzea baino:

\begin{abstract}
Jakina, beste inoren lana itzultzean ezin autoretza asumitzera ausartu, fideltasuna mantentzea da araua. Bestelako askatasunak nahiko kriminalizatuta daude. Nik autoretza zalantzan ipintzen eta literaltasunaren lege horiek apur bat haustera jolastu dut batzuetan, Izkiriaturik aurkitu ditudan ene poemak eta Hezurrezko xirulak liburuetan adibidez, baina tira, arauen gerizpean bizi behar. Neure testuekin desberdina da. Itzultzaileak lana eginez gero bere autoretzat onartu dut, hor konpon. Baina neure testua itzuli dudanean, testuaren autoretza asumituz, orduan zeharo berridatzi dut orijinala.
\end{abstract}

(Sarrionandia, 2013)

Autoretza da, hortaz, itzulpenaren fideltasunaz jardutean gogoeta ardazten duen auzia; autoretzari loturik, eta bere testuen itzulpenetan, kasurako, bere ahotsarekin bat egiteari ematen dio garrantzia Sarrionandiak:

12 Begiratu, besteak beste, Aiora Jakaren hitzak Garazi Arrulak idatzitako mintegiko 1. saioaren kronikan (Arrula, 2016a): <http://www.eizie.eus/Jarduerak/itzultzaile_berriak/iibb_kronika0620.pdf>. 
Ez dakit liburu baten autorea izatea inportantea den, baina nire ustez itzultzailea ere autorea da, igual autorea bera bezainbeste. Nik ez dut nire hizkera ezagutzen nire liburuen erdarazko bertsioetan. Gazteleraz gogorra ere egin zait batzuetan, ez itzulpenaren oker konkretuengatik, baizik nik beste era batean idatziko nukeela pentsatu dudalako, beste tono batean edo ez dakit. Orduan, Lagun izoztuaren itzulpenaren argitalpena geldirik dago neuk berridazteko zain, eta Moroak gara behelaino artean? guztiz berridatzi behar izan dut. Autore moduan testua aldatzeko libertatea ona dela uste dut... Itzulpena ez zait gaizki iruditzen, baina testua itzultzailearen gauza bilakatzen da niretzat. Autoretza asumitzeko, erdarazko bertsioa neuk idaztera behartuta nagoela sentitzen dut.

(Sarrionandia, 2013)

Idazle zein itzultzaile, testua erredaktatzen duen hori da autorea, eta bere testuen kasuan, ez du bere ahotsarekin bat egiten itzulpen-prozesuan zuzenean parte hartu ezean, hortaz. Bada, norberaren testua itzuli/berridatzi eta testuak bizi izaten duen eraldaketari loturik, bitxikeria bat ere ekarri digu:

Honi buruz, kasu bitxi bat gertatu zitzaidan artikulu batekin. 2000. urte aldean artikulu bat idatzi nuen prentsarako: «Euskal Herriaren bila». Itzulpena eskatu zidaten, orduan berridatzi egin nuen eta ia batera argitaratu zen gaztelerazko bertsioa: «Contra la idea de necesidad». Orduan, ustekabean, euskarazko artikulua gaztelerazko itzulpen batekin argitaratu zen, eta erdarazko artikulua euskarara itzuli zuen beste batek...

(Sarrionandia, 2013)

Sarrionandiaren testu asko itzuli dituzte hango eta hemengo itzultzaileek ${ }^{13}$, eta modu askotara jardun izan dute idazlearekin lankidetzan ${ }^{14}$. Sarrionandiak berak emandako informazioari jarraikiz, Narrazioak lanaren katalanerako (itz.: Josep Daurella) eta italierako (itz.: Roberta Gozzi) bertsioetan eta Ni ez naiz hemengoa lanaren gaztelaniako (itz.: Begoña Montorio) eta alemanierarako (itz.: Ruth Baier) bertsioetan, esaterako, idazleak ez zuen itzulpenean parte hartu. Aurreragoko beste batzuetan bai, ostera; baina, gorago aipatu dugunez, bere ahotsa ezagutzeak (edo ez) eragin egiten du argitalpenean; hara zein den, esaterako, Lagun izoztua (Elkar: 2001) lanaren alemanezko bertsioaren (itz.: Petra Elser eta Raul Zelik) eta gaztelaniazko bertsioaren (Xabier Diaz Esarte) istorioa:

13 Begiratu EIZIEren Nor da Nor atarian Sarrionandiaren testuen itzulpenen zerrenda: <http://nordanor. eus/bilatu?n=l\&e_or=\&e_st=\&e_xt=\&e_eg=Sarrionandia\&e_it=\&e_ar=\&e_ge=\&e_sh=\&e_xh=\&e_ sd1 $=\&$ e_sd2 $=\& e_{-} \_x d 1=\& e_{-}$xd2 $=>$.

14 Mintegi honetan bertan eman ditu zenbait argibide Eva Linazasorok, Sarrionandiarekin izandako itzulpen-kolaborazioari loturik. Begiratu, beraz, Garazi Arrulak idatzitako 3. saioko kronika (Arrula, 2016c). 
Gaztelerara itzuli zen lehenengo eta zalantza handiak sortu zizkidan testuak. Ze nobelaren gaia nahiko behelainotsua da eta, nire kriterioan, oso inportantea zen lengoaia bera, halako lengoaia tono berezi bat. Itzulpena (Xabier Diaz Esartek egina) berez ez dago gaizki, baina ez dut uste lengoaia egokia duenik, eta berridatzi behar dudala pentsatzen dut. Hagatik ez da argitaratu oraindik. Alemanez ez dakidanez, ezin nuen ezer zuzendu, eta halako lana hartu zutenez gero, ba baimena eman nien argitaratzeko. Raul Zelik, gainera, oso fidagarria iruditu zitzaidan.

(Sarrionandia, 2013)

«Lengoaia», «tonu» edo «ahots» kontuak ez eze, arrazoi kulturalek ere eragin dute Sarrionandiarengan inork itzulitako gaztelerazko bertsioa berridazteko beharra, bai eta gainerako testuen itzulpenak berridatzitako gaztelerazko testutik egiteko gomendioa eman beharra ere. Bada, hauxe dio Moroak gara behelaino artean? (Pamiela, 2010) lanaren gaztelerazko (itz.: Javier Rodríguez eta autorea) eta katalanezko (itz.: Ainara Munt Ojanguren) bertsioei buruz:

Gazteleraz itzultzaileak egin behar zuen, atalka hasi zitzaidan bere lana bidaltzen, nik zuzentzeko. Baina, atalik atal, goitik behera berridatzi nuen gazteleraz liburua, alde batetik gaztelerazko testuarekin konforme ez nengoelako eta bestetik interlokutore espainol batentzat beste gai batzuk ere aipatu behar zirela iruditzen zitzaidalako. Hala, liburuak euskaraz baino 200 orrialde gehiago ditu gazteleraz. Katalanezko bertsioa, Ainarak euskarazkotik hasi zuen, baina nik gaztelerazkotik egiteko errepikatu eta hala jarraitu zuen bi liburuei begira. Bai Javierrekin eta bai Ainararekin harremana izan nuen itzulpen lana egiten ari zirela. Biek lagundu zidaten testuari zuzenketa egokiak egiten.

(Sarrionandia, 2013)

Sarrionandiak itzulpenean esku hartzeko ohitura izan du, itzulpen kolaboratiboa egitekoa, hizkuntza ezagutu izan duenean. Sarrionandiak «bere» egin nahi ditu testuak, eta hargatik egin zien hasieran aipatu dugun itzulpen-lantegiko itzultzaileei oharra: «egin ditzatela testuak bere, erdi idazle erdi itzultzaile izateko», mintegiko itzultzaileen zalantzei erantzuteko bidalitako mezuetako batean (Arrula, 2016b).

Urretabizkaiak ere erantzun zien mintegiko itzultzaileen galderei, eta lehendik ere itzulpenari lotuta agertu izan ohi duen ezinegon bat agertu zien, ez zezaten bere testuetan hizkuntzaren maila handitu eta hizkera ponpoxotik aldendu zitezela, idazketaprozesuan kendu eta kendu aritu izan zela bera, eta berdin egin behar dela itzulpenean (Arrula, 2016a).

Norberaren lanen itzulpenez galdetuta, autoitzulpen bakarra egin duela dio Urretabizkaiak: "Zergatik, Panpox gaztelerara itzuli nuen eta horretan oinarrituta itzuli zuten katalanera. Gero, argitaletxeak bere kabuz gaztelerako bertsioa ere argitaratu zuen» (Urretabizkaia, 2013). Ez du autoitzulpenik egin aurrerantzean eta, idazle 
garaikide gehienen joerarekin bat, itzultzaileen esku utzi izan ditu bere testuen itzulpenak $^{15}$ :

Handik aurrera, ez dut nire lanik itzuli. Pentsatu nuen itzultzaile izateko ez dela aski hizkuntza hura ezagutzea, itzulpengintza ofizio bat dela. Beraz, beste norbaitek itzuli zituen Saturno, Koaderno gorria eta Hiru Mariak. Nik, gero, itzulitakoa kontrolatu egin dut eta zuzendu. Batez ere hizkuntza mailari dagokionez. Adibidez, baldin eta itzultzaileak nik gazteleraz erabiliko ez nukeen hitza jartzen badu, kendu eta nik erabiliko nukeena jarri izan dut. Normalean itzultzaileak hitza gehiegi jantzi izan duenean gertatu izan da.

(Urretabizkaia, 2013)

Edonola ere, Urretabizkaiak berak «Deserria itzultzen» itzulpen-lantegian aipatu zuenez, kazetaritza-lanetan ari denean «ez du maite elkarrizketatuak testua kontrolatzeko gogoa erakusten duenean; beraz, ezin halakorik inori eskatu» (Arrula, 2016a).

Euren testuen itzultzaileekin harremana izan duten arren, Urretabizkaiak eta Sarrionandiak aitortzen dutenez, ez dute euskal itzultzaileen eremua ezagutzen eta ez dute euren burua eremuko partaidetzat; halaxe aitortzen dute, behintzat, euskarazko itzultzaileekin lotura duten, tarifak ezagutzen dituzten, euren burua itzultzailetzat jotzen duten zein EIZIEko kide diren galdetuta (Sarrionandia, 2013 eta Urretabizkaia, 2013).

Euskarazko itzulpenak irakurtzen ote dituzten galdetuta, biek ala biek diote gurago dutela jatorrizko hizkuntzan irakurri. Urretabizkaiak dioenez, irakurri izan zuen bolada batean euskarazko itzulpenik, «baina iruditzen zitzaidan itzulpena nahiko ortopedikoa zela» (Urretabizkaia, 2013). Noski, euskal literatur eremua osatzen hasi zeneko itzulpen haietaz ari da, ezen egoera asko aldatu da, Sarrionandiak berak dioenez:

Nahiago dut orijinalean irakurri, baina euskal bertsio bat heltzen zaidanean eta ondo eginda dagoela ikusten dudanean, gustura leitzen dut. Euskal bertsio ederrak irakurri ditut, Xabier Olarrak egindako poliziako amerikanoenak adibidez. Lehen ez genuen euskaraz hainbeste literaturarik eskura. Sasoi onean gaude, alde horretatik.

(Sarrionandia, 2013)

Izan ere, biek ala biek begi onez dakusate euskal itzulpen-eremuak euskal literaturari egindako ekarpena: euskaratik beste hizkuntzetara egindako itzulpenez denaz bezainbatean, «euskal literatura itzultzea izan da azken hamarkadetako iraultzarik handiena ${ }^{16}$,

15 Begiratu Arantxa Urretabizkaiaren lanen itzulpenen zerrenda EIZIEren Nor da Nor atarian: <http://nordanor.eus/bilatu?n=1\&e_or $=\& e_{2}$ st $=\& e_{-} \mathrm{xt}=\& \mathrm{e}$ _eg=Urretabizkaia\&e_it=\&e_ar=\&e_ge=\&e_sh=\&e_ $\mathrm{xh}=\& \mathrm{e} \_$sd $1=\& \mathrm{e} \_s \mathrm{~s} 2=\& \mathrm{e} \_\mathrm{xd} 1=\& \mathrm{e} \_\mathrm{xd} 2=>$.

16 Bere kasuan, «la chica» izatetik «la vasca» izatera igaro zen, gaztelerara itzuli zutenean. Legitimazio-bide bat izan da, nolabait, itzulpena Urretabizkaiarentzat. Ikusi Ibarluzea, 2015 eta G. Arrula, 2016a. 
irakurle taldeekin batera» Urretabizkaiaren ustez (Arrula, 2016a); eta euskarara egindako itzulpenei buruz hauxe dio Sarrionandiak: «Literaturaren aldetik, kalitate handiko produktuak ikusten ditut. Itzulpen-sistema ez dut ondo ezagutzen, baina igartzen da jada aparatu zabala dela. Zeure ikerketa bera ere horren seinalea da apika» (Sarrionandia, 2013).

\section{ONDORIO GISA}

Urretabizkaiaren eta Sarrionandiaren itzulpenarekiko atxikimendua, jarduna eta usteak ezin uler daitezke euren gainerako jardunarekin eta bizi izandako gizarte-egoera historikoarekin, politikoarekin eta kulturalarekin lotu gabe.

Biek ala biek itzulpenaren bidez erantzun zieten, nolabait, jarduna hasi zuten uneko kultur beharrizanei: euskarazko material faltari erantzuteko hasi zen itzultzen Urretabizkaia; edonola ere, beharrizan hori asez eta eremua profesionalizatuz joan den heinean, itzulpen-jardunetik urrundu da. Sarrionandiak, bestalde, itzulpenaren bidez erantzun zion idazten hasi zen garaiko euskal literaturaren egoerari: literatura egiteko modu klasikoa gainditu eta euskal literatura berritzeko tresnatzat jo zuen itzulpena iurretarrak.

Orduz geroztik, bi autoreentzat zubi bat izan da itzulpena: etapa sozial eta pertsonal biren arteko zubia Urretabizkaiarenean (autoitzulpen bat kenduta, hasierako etapa hartatik aurrerakoan ez zaio itzulpenari lotu); irakurketaren eta testua bereganatzearen artekoa, sormenaren eta interpretazioaren artekoa, Sarrionandiarenean (horretan, bat dator Sarrionandiaren habitusa, esaterako, Aurelia Arkotxa idazlearenarekin).

Urretabizkaiak, alde horretatik, bat egiten du hainbat idazle garaikiderengan nabari den joerarekin: gero eta gehiago bereizten dira sormen- eta itzulpen-jarduna (Ibarluzea, 2015).

Ez da hala gertatzen Sarrionandiarenean euskal literatura itzuliaren eremuan: literatura ulertzeko eta egiteko moduarekin lotzen du itzulpena Sarrionandiak, eta, beraz, garai jakin bateko gizarte-beharrizan bati erantzuteko bidea izateaz gainera, jolas gisa ere erabili izan ditu sormenaren eta itzulpenaren arteko muga, itzulpen apokrifoak eta fikziozko itzultzaileak. Gainera, autoretzaz gogoeta egiteko bidea jorratu du bere itzulpen-esperientzietatik abiatuta. Idazle garaikideenean gertatu ohi den moduan (Ibarluzea, 2015), arrazoi literarioengatik hautatu izan ditu itzulgaiak Sarrionandiak (enkarguz euskarazko itzulpen bakarra argitaratu du Iurretakoak, eta ez da hala izaten itzultzaile profesional gehienen kasuan, enkarguz aritzen baitira). Baina bestelakoa izan da bere jardunbidea beste hizkuntza batzuetako itzulpen-eremuetan: ogibidetzat jo izan du beste hizkuntza batzuetan egindako itzulpena, eta are gehiago, ezizenak erabili izan ditu erdal eremuren batean idaztean zein itzultzean; beste hitz batzuetan esateko: Sarrionandia sortzaile eta itzultzaile da, biak bat, euskal eremuan, eta ez da Sarrionandia, ezpada itzultzaile profesional ikusezina, beste hizkuntza batzuetako itzulpen-eremuetan. 


\section{BIBLIOGRAFIA}

Arrula, G., 2016a, «Ekainaren 20ko saioaren kronika», <http://www.eizie.eus/Jarduerak/itzultzaile_berriak/iibb_kronika0620.pdf>.

— 2016b, «Ekainaren 21eko saioaren kronika», linean: <http://www.eizie.eus/Jarduerak/itzultzaile_berriak/iibb_kronika0621.pdf>.

— 2016c, «Ekainaren 22ko saioaren kronika», <http://www.eizie.eus/Jarduerak/itzultzaile_berriak/IIBB_kronika0622.pdf>.

Bourdieu, P.; Wacquant, L., 1992, Réponses: pour une sociologie réflexive, Paris, Editions du Seuil.

IbARluZeA, M., 2015, «The Translation Habitus of Contemporary Basque Writers", Estudios de Traducción, 5, 59-75, <http://revistas.ucm.es/index.php/ESTR/ article/view/49410>.

JaKA, A., 2012, Itzulpenari buruzko gogoeta eta itzulpen-praktika Joseba Sarrionandiaren lanetan, Bilbo, Euskaltzaindia, «Iker», 28, <http://www.euskaltzaindia. eus/dok/ikerbilduma/75892.pdf>.

SARRIONANDIA, J., 2013, «Itzulpen-ohiturei buruzko galdetegiaren erantzunak», in M. Ibarluzea, «Hamabost euskal idazle garaikideri itzulpen-ohiturei buruz egindako galdetegia», argitaragabea.

UrRetabizkaia, A., 2013, «Itzulpen-ohiturei buruzko galdetegiaren erantzunak», in M. Ibarluzea, «Hamabost euskal idazle garaikideri itzulpen-ohiturei buruz egindako galdetegia», argitaragabea.

Vizcarra, F., 2002, "Premisas y conceptos básicos en la sociología de Pierre Bourdieu», Estudios sobre Culturas Contemporáneas, viII, 16, 55-68, <http:// www.redalyc.org/articulo.oa?id=31601604>. 


\section{LABURPENA}

\section{Urretabizkaiaren eta Sarrionandiaren itzulpen-habitusak}

P. Bourdieuren arabera, gramatika unibertsal moduko bat da habitusa, barneratutako jarrera-sistema bat, zerikusia duena norberaren pertzepzioekin, pentsamenduekin, diskurtsoarekin, ekintzekin eta praktikekin. Euskal literatura itzuliaren eremuko parte dira Urretabizkaia eta Sarrionandia, eta, hortaz, habitus jakin bat dute, eremu sozioekonomiko, politiko eta kultural jakin bati lotutakoa. Bi idazleen itzulpen-habitusaz ariko gara hemen; alegia, bi idazleen itzulpen-ohiturez eta jarrerez, itzulpenarekin duten loturez, euskal itzulpengintzari egindako ekarpenez eta itzulpenak eurengan utzitako lorratzaz. Euren hizkuntzen ikasketa-prozesuaz, itzulpenarekin izandako loturaz, itzulpen-esperientziez, euskal itzulpengintzari buruzko iritziaz eta itzulpena fikzioan baliatu izanaz galdetu genien 2013an, eta orduan egindako galderen erantzunak jaso, azaldu eta elkarrekin erkatu ditugu artikulu honetan.

Gako hitzak: euskal literatura; literatura itzuliaren eremua; Urretabizkaia; Sarrionandia; habitus.

\section{RESUMEN}

\section{El habitus traductológico de Urretabizkaia y Sarrionandia}

Según P. Bourdieu, el habitus es una especie de gramática universal, un sistema de actitudes interiorizadas relacionadas con las percepciones, el pensamiento, el discurso, las acciones y las practicas de cada agente. Urretabizkaia y Sarrionandia forman parte del campo de la literatura traducida vasca y, por lo tanto, cuentan con un habitus concreto, estrechamente ligado al campo socio-económico, político y cultural en el que se adscribe el campo en cuestión. Abordaremos aquí los hábitos traductológicos y las actitudes en torno a la traducción de los dos escritores citados; es decir, nos ocuparemos de los usos que han hecho de la traducción, de sus aportaciones y de la huella que la traducción ha dejado en ellos. En este artículo retomaremos las entrevistas que les realizamos en 2013 sobre sus procesos de aprendizaje de lenguas, sobre su relación con la traducción, sobre sus experiencias de traducción, sobre sus opiniones en torno a la traducción vasca y sobre el hecho de haber integrado la traducción en sus obras de ficción. Finalmente, explicamos y comparamos sus respuestas.

Palabras clave: literatura vasca; campo de la traducción literaria; Urretabizkaia; Sarrionandia; habitus. 


\begin{abstract}
The translation habitus of Urretabizkaia And Sarrionandia

P. Bourdieu defines habitus as a universal grammar, as a system of assimilated dispositions related to perceptions, thoughts, discourses, acts and practices. Urretabizkaia and Sarrionandia are part of The Field of Translated Basque Literature. Therefore, both of them have a specific habitus that should be understood linked to the socio-economical, political and cultural field in which The Field of Translated Basque Literature is located. In this paper, I will focus on Urretabizkaia's and Sarrionandia's translation-habitus: I will discuss their translation habits, their attitudes towards translation, their links to translation, their translation experiences, their contribution to Basque translation and the trace translation has printed on them. For that purpose, I will get back to a questionnaire they answered in 2013, and I will comment and compare their answers to the questions about their language acquisition, their involvement with translation, their experiences with translation, their thoughts about Basque translation and their use of translation or translators in their fictional works.
\end{abstract}

Keywords: Basque literature; the field of literary translation; Urretabizkaia; Sarrionandia; habitus. 
ISSN: 0046-435X ISSN-e: 2530-5832 